\title{
Definition of chemical indicators plant fodders of the Chuvash Republic
}

\author{
C Elena G. Zinovjeva, ${ }^{1}{ }^{+}$Pavel I. Fedorov, ${ }^{2}$ Svetlana N. Smirnova, ${ }^{1}$ \\ Svetlana V. Jhitar, ${ }^{1}$ Natalia N. Yaschenko, ${ }^{1}$ Svetlana A. Markova, ${ }^{1}$ \\ and Ekaterina I. Zajivihina ${ }^{1}$ \\ ${ }^{1}$ General, Inorgsnic and Analitical Chemistry Department; ${ }^{2}$ Organic and Pharmaceutical Chemistry \\ Department. Chuvash State University. Moskovsky Ave., 15. Cheboksary, 428015.Chuvash Republic. Russia. \\ Phone:+7 (8352) 45-24-68.E-mail: zinelgen@mail.ru
}

*Supervising author; ${ }^{+}$Corresponding author Keywords: vegetable raw materials, fodder raw materials, stern, chemical indicators, solid, crude fat, crude protein, crude cellulose, crude ashes, calcium, phosphorus.

\begin{abstract}
This review presents the results of a comprehensive study of various chemical indicators of plant feed for farm animals. By standard techniques photometric, titrimetrichesky and gravimetric determined by ways the content of solid (GOST 31640-2012), crude fat (GOST 13496.15-97), a crude protein (GOST 13496.4-93), crude cellulose (GOST 31675-2012), crude ashes (GOST 26226-95), calcium (GOST 26570-95) and phosphorus (GOST 26657-97). As objects of vegetable fodder raw materials are considered wheat, maize, lucernous hay, scallop hay, rapeseed extraction cake, sunflower extraction cake, rapeseed cake, barley, peas, lucernous hay, corn silos, growing and/or prepared in the territory of Krasnarmeysky, Vournashky and Chuvilsky regions, It has been revealed that rapeseed and sunflower extraction cake, as well as rapeseed cake, have an increased value of raw fat in the territory of the Vournar district compared to the rest of the Chuvashia region. According to the chemical indicator of dry matter, all fodders comply with the standards in Yadrin, Wournar and Civilsky districts; By the indicator of raw protein - most fodders comply with the standards in Civilsky, Krasnoarmeysky, Yadrin and Wournar districts; By the indicator of raw fiber - the samples from Civilsky district meet the standards, in Yadrin and Krasnoarmeysky district minor deviations were found, and in Cheboxary and Wournar districts the indicators do not fully correspond; By the indicator of raw fat corresponds to the norms of Yadrin district, in Civilsky and Krasnoarmeysky districts minor deviations were found, and in Cheboxary and Wournar districts the indicators do not correspond to the norm; In terms of raw ash - in all areas the value is exceeded; Calcium content - in almost all areas there is an excess of the norm; In terms of phosphorus content - meets the standards of the Wournar district, in the Civilsky and Yadrin districts minor deviations were found, and in the Krasnoarmeysky and Cheboxar districts the indicators do not correspond. All of the areas studied by us, the best raw material indicators of plant feed in Yadrin and Civilsk districts of the Chuvash Republic.
\end{abstract}

\section{References}

[1] Farm animal feeding norms and rates. Handbook. 3rd edition revised and supplemented. Under ed. A.P. Kalashnikov, V.I. Fisinin, V.V. Schchoglova, N. I. Kleimenova. Moscow: Russian Agricultural Academy. 2003. 456p. (russian)

[2] R.A. Shurkhno, F.Y. Ahmadullin, A.S. Sirotkin, L.F. Galantseva, O.N. Ilinsky. Analysis of nutritional value of plant fodders and secondary raw materials. Journal of Kazan Technological University. 2014. Vol.17. No.21. P.223-228. (russian)

[3] O.E. Privalo, N.A. Chepelev, E.A. Kargapolova, V.L. Written, L.E. Malyhina. Justification of the composition of diets in the case of cows, based on the assessment of the productive action of the used fodders. Journal of the Kursk State Agricultural Academy. 2013. No.4. P.57-60. (russian)

[4] GOST 31640-2012 Stern. Dry matter determination methods.

[5] GOST 13496.4-93 Sterns, compound feeds, formula-feed raw materials. Methods for determination of nitrogen and crude protein content.

[6] GOST 31675-2012 Stern. Methods for determining raw fiber content using intermediate filtration.

[7] GOST 13496.15-97 Sterns, compound feeds, formula-feed raw materials. Methods for determining raw fat content.

Kazan. The Republic of Tatarstan. Russia. (C)Butlerov Communications. 2020. Vol.61. No.2. 
Full Paper _ E.G. Zinovjeva, P.I. Fedorov, S.N. Smirnova, S.V. Jhitar, N.N. Yaschenko, S.A. Markova, and E.I. Zajivihina [8] GOST 26226-95 Stern, compound feeds, formula-feed raw materials. Methods for determining crude ash. [9] GOST 26570-95 Stern, compound feeds, formula-feed raw materials. Calcium definition methods.

[10] GOST 26657-97 Stern, compound feeds, formula-feed raw materials. Method for determining phosphorus content. 